$\left.\begin{array}{c}\text { INTERNATIONAL JOURNAL OF } \\ \text { ORGANIZATIONAL LEADERSHIP }\end{array}\right) \begin{gathered}\text { INDUSTRIAL } \\ \text { MANAGEMENT } \\ \text { INSTITUTE }\end{gathered}$

\title{
Strategic management and its application in modern organizations
}

\author{
Neda Esmaeili \\ Project Coordinator, Petro Barasun International Co. (Ltd.)
}

\begin{abstract}
Keywords:

Strategy, Management,

Strategic Management

Correspondence:

Neda.Esmaeili@yahoo.com

The aim of this study is to contribute to the existing research in the field of strategic management. The main responsibility of managers in the modern industrial world is to achieve the objectives of the organizations and make the organizations successful. Accomplishing objectives needs regular planning and continuous improvement of the plans. It also requires knowledge about the internal and external environment of organizations. Strategic management provides the managers with efficient solutions to solve the problems of the organizations through dynamic, provident, holistic, and contingent principles. Strategic management also makes the managers able to develop better strategies for the survival of the organizations through taking advantage of more regular and logical methods. Therefore, this article is an attempt to study different aspects of strategic management through reviewing the related literature and the researchers' point of view. In addition, this paper tries to consider the importance of implementing strategic management in organizations to accomplish future objectives.
\end{abstract}

(C)AIMI Journals

\section{Introduction}

One of the main objectives of managers is to gain profit based on the activities of organizations. To achieve this objective, the managers are faced with a variety of environmental and management challenges. Therefore, they should plan more effective and efficient plans to accomplish the objectives. Considering the crucial effect of strategic management on the design and implementation of organizational plans, it can provide creative methods and solutions to prevent the managers from taking inappropriate and 
individual measures for designing the future plans of organization. It also helps the managers to improve the socioeconomic status of organizations through collecting data about the status of the rival companies, market, prices, distributors, government, and all people who are related to the organization.

It is argued that political, economic, and social changes of the society have considerable effect on organizations and these factors have significant role in the survival or breakdown of organizations. Therefore, considering the fact that strategic management has been created in environmental challenges and competitions, it can be used in the other fields of management since it involves strong principles and criteria.

Guerras-Martin, Madhok, and Montoro-Sanchez (2014) stated that strategic management is an almost a new field of study and it was developed in the mid-nineteenth century from the preliminary studies of Chandler (1962), Ansoff (1965), and Andrews (1971). Since then, it has been improved substantially, and it is now acknowledged as a perfect and wellestablished field of study in management.

In recent years, there have been many investigations and studies about strategic management and different researchers have concentrated on different applications of the issue. A few researchers, namely Gannon, Roper, and Doherty (2015), Yorio, Willmer, and Moore (2015), Lengnick-Hall, Lengnick-Hall, and Rigsbee (2013), and Al Hijji (2014) have conducted a number of studies in this field. Yorio et al. (2015) have dealt with the application of strategic management at health and safety management systems; Lengnick-Hall et al. (2013) have investigated strategic human resource management; and Al Hijji (2014) has studied strategic management model for academic libraries. Therefore, considering the importance of the issue, the purpose of this study is to investigate different aspects of strategic management and shed lights on the importance of implementing it in organizations to make them more successful.

\section{Strategy}

A variety of definitions have been presented for the term strategy by a number of managers and researchers based on their different points of view. In this paper, the definition of strategy is presented according to strategic managers' viewpoint. Therefore, the general definition and the varieties presented by Mintzberg (1987) are of great concern in this article.

Mintzberg (1987) believes that it is not possible to present a single definition for strategy because general concepts are usually used in different ways. To capture this complexity, 
Mintzberg (1987) articulates what he has labeled as "the five Ps of strategy", namely strategy as a plan, ploy, pattern, position, and strategy as a perspective. According to Mintzberg (1987), understanding how strategy can be viewed as a plan, ploy, position, pattern, and as a perspective is of great importance and understanding each of these five ways of thinking about strategy is necessary for understanding what strategy is, but none of them alone is enough to master the concept of strategy.

First of all, strategy is considered as a plan. Based on this definition, strategy is a kind of consciously intended course of action or a set of useful guidelines which is provided for dealing with a specific situation or event in future (Mintzberg, 1987). According to this definition, strategies have two main characteristics; they are made in advance of the actions to which they apply and they are developed consciously and purposefully (Mintzberg, 1987). Drucker (1974) believes that strategy is a purposeful activity and it is in essence designed to be put into action. Glueck (1976) and many other outstanding researchers in the field of management have also accepted strategy as a plan. Glueck (1976) has defined strategy as a unified, comprehensive, and integrative plan which is designed to assure that the basic objectives of the organizations are accomplished.

Second way of viewing strategy refers to viewing it in terms of ploys. In this view, in addition to the characteristics mentioned in strategy as a plan, strategy has a special quality which results in clever trick or maneuver against opponents or competitors. In strategy as ploy, the focus is on the dynamic, creative, and competitive aspects of strategy to enhance success. (Mintzberg, 1987)

Strategy as pattern is the third way to view strategy. As the result of the development of the concept of strategy, which can be both a plan and a ploy, the most crucial point is to implement the strategies. Therefore, strategy is defined as a pattern, especially a pattern in a stream of actions, which is drawn at the decision-making stage. This definition is presented for the implementation of strategies. Based on this definition, strategy should also involve all the movements and functions of the organizations for fulfilling the plans and ploys (Mintzberg, 1987).

In the next $\mathrm{P}$, strategy as a position, strategy is considered as a tool for locating the organization in what is called environment by the organization theorists. According to this view, strategy is considered as a mediator or coordinator between the organization and environment; that is, between the internal and external context (Mintzberg, 1987). 
The fifth and final $\mathrm{P}$ is strategy as a perspective which focuses on the inside of the minds of the executive running a company. Strategy as perspective involves knowing how executives interpret the competitive environment surrounding the company. This definition not only involves the strategic quality of a situation in environment (i.e., the definition of strategy as position), but it also consists of a deep approach for understanding the surrounding world (Ali-Ahmadi, Taj al-Din, \& Fethullah, 2012). Mintzberg (1987) believes that the fifth definition suggests that strategy is a concept, and this conceptual meaning, in fact, proposes that "strategies are abstractions which exist only in the minds of interested parties.

\section{Strategic Management}

Every scholar in the field of management has presented different definitions for management according to their own knowledge and opinion, and every scholar has had different methods for determining the meaning of this concept. The evaluation of these opinions underscores the fact that there is no general and consistent definition for the term, and in fact, every researcher has considered it from his ไher own viewpoint.

Follett (as cited in Barrett, 2003) defines management as the art of getting things done through people. According to this meaning, everyone who can have the things done by the others' energy is considered as a successful manager. In other words, a successful manager is the coordinator and conductor of group activities for accomplishing the desired objectives of the organization with maximum efficiency.

On the other hand, Safi (1995) believes that management is coordinating human and financial resources for achieving organizational objectives. Therefore, management is an efficient process for solving the problems related to achieving objectives through effective application of rare resources in a changing environment. It is also defined as the science and art of establishing, coordinating, leading, and controlling group activities to accomplish group members' common objectives. In addition, it is considered as the art of finding and employing the most qualified personnel, combining their physical and intellectual assistance, and aligning their assistance with the objectives of the company. Finally, management is mentioned as a process for planning, organizing, leading, and controlling all the members of the organization and also the process for using all the organizational resources for achieving predicted and claimed objectives. 
However, considering the modern extension of management which is called strategic management, it can be claimed that strategic management guarantees the profit of organizations using suitable and efficient organizational strategies. According to this idea, efficient strategies are developed based on the needs of organizations at a certain period of time. Daft (2010) believes that strategic managers should be able to plan and control the activities because controlling activities is not possible without using efficient plans. He states that the implementation procedure of plans can be monitored using suitable strategies. In other words, strategic management is mentioned as the process which involves strategic perspective; that is, managers who follow strategic management are able to recognize and analyze the strategic topics of the organization and know the objectives of the organization to choose the most suitable strategy (Daft, 2010).

In addition, it is claimed that strategic management consists of the art and science of formulation of the activities of organizations and evaluation of the multidimensional decisions for achieving objectives through integration of management factors, marketing, financial affairs, production or development services, data collection system, etc. (Davari, 2001). Strategic management is also considered as the art and science of taking, implementing, and evaluating decisions about multiple duties of the people working in organizations to enable the organizations to accomplish long-term objectives.

\section{The Process of Strategic Management}

According to David (2006), organizations use different procedures for developing and administering the activities related to the strategic management. In fact, organizations which have more advanced plans have developed more detailed procedures. In addition, the organizations which have a variety of actions are more willing to use developed systems of strategic management because they are more dependent on the variety of their products, market, and technology (David, 2006).

However, in spite of the differences in the details and the levels of formality, the main components of the models used for analyzing the activities of strategic management can be categorized into three general parts, namely developing and planning of strategy, execution of strategy, and monitoring developments, and progress. Figure 1 shows the components of the cycle of strategic management. 


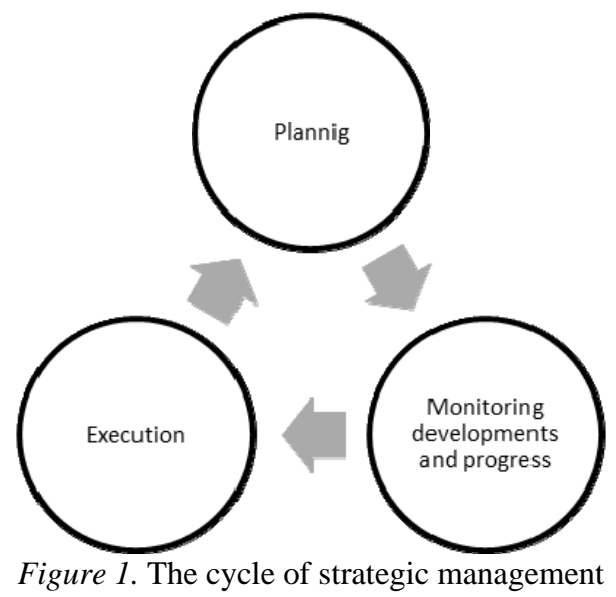

Considering the cycle of strategic management, it can be mentioned that the first step in strategic management is developing and planning of strategy. At this stage, the mission of the organization is specified and the internal and external factors are evaluated to determine the opportunities, limitations, strengths, and weaknesses of the organization and to enable the organization to determine the objectives and strategies in different levels.

Next, there is the second component of strategic management (i.e., implementation of strategy) which involves putting the strategies specified at the development stage into action. In order to implement the strategies, first of all, the objectives and policies of the organization are determined according to the strategies and the missions of the company and then the resources are allocated based on the objectives and policies. After that, the objectives and policies are directed based on a suitable framework to implement the strategies.

The last component of strategic management is monitoring developments and progress. During this stage the probable changes in internal and external factors are specified, and the probable effect of these changes on the missions, objectives, strategies, and implementation procedures are evaluated. In addition, a suitable methodology is developed for the implementation of every stage and the implementation of the strategy is investigated from different angles. In the end, the acquired results and the best method for acquiring the results are assessed to recognize and remove the probable deviations.

However, whatever the components of strategic management, some main factors should be considered in its procedure. The most essential factors in the procedure of strategic management consist of the environment for the implementation of plans (i.e., relationships and compatibility), strategies and plans (i.e., objectives, procedures, policies, and practical 
plans), organizational structure (i.e., duties, responsibilities, authority, control system, etc.), and the process of interior relationships.

According to another point of view, strategic management of an organization consists of a cycle of strategic planning, operational planning, budgeting, supervision, and evaluation. Operational planning puts the strategies of the organization into action. Therefore, complete harmony is required between these components to make an organization successful. Nowadays, almost all advanced companies around the world (both private and public companies) use strategic management for managing and controlling their organizations. Operational planning is also considered as one of the main components of strategic management.

Therefore, it can be argued that planning is one of the five main principles of management. At the present modern era, planning has changed into strategic planning as the result of the modernization of business environment. Strategic planning is in direct contact with the objectives of the company and it is a long-term planning. In other words, strategic planning provides a clear image of the future of the organization.

It is claimed that strategic planning helps organizations achieve their objectives and the organizations which take steps according to some predetermined plans are more successful. Therefore, strategic planning is one of the main actions of successful organizations. It is also argued that strategic planning determines the present status of the organization and specifies logical, realistic long-term objectives through getting information about the environment of the organization, its strengths and weaknesses, the rivals and similar companies, and the probable opportunities and threats. Strategic planning also expresses that the organizations should take firm steps for accomplishing objectives.

On the other hand, Najaf-Beigi (2011) mentions that strategic planning will be successful on condition that it is realistic and developed in a way that guarantees achieving objectives. He states that strategic planning should be evaluated and updated during the implementation stage.

Consequently, strategic planning is considered as a systematic method which supports and verifies the process of strategic management. According to Galloway (1990), strategic planning is a sort of systematic forethought which involves eight stages of determining the missions and long-term objectives, setting goals and dividing the missions into quantitative and qualitative short-term objectives, specifying main strategies and procedures for achieving objectives, formulizing micro- and macro-policies, developing procedures, drawing up a 
constitution, developing primary and secondary operational and administrative plans, and presenting budget according to the currency.

\section{Necessity and Advantages of Strategic Management}

Strategic management is both necessary and highly beneficial to the organizations. Considering the rapid social and environmental changes and the necessity of aligning organizations to these changes, organizations need to develop plans which enable them to tolerate and even overcome these political and socioeconomic fluctuations. Therefore, the ability to anticipate the future, get information about the environment, and have efficient plans for success in the future requires strategic management and planning.

Strategic management is also considered as a great advantage for organizations. The principal advantages of strategic management consist of warning against problems before their occurrence; preparing for environmental changes and the activities of rivals, and not being surprised by these factors; producing favorable reactions to the changes; providing realistic attitudes toward the problems; facilitating the recognition and usage of opportunities; minimizing the adverse effects of bad conditions and unfavorable changes; helping the managers to relate crucial decisions to determined objectives; making the time and resources allocated to recognized opportunities more effective; providing group activities according to combining the different staff's duties; developing a framework for the interior relationship of the personnel; granting the organization a better competitive advantage compared to the rivals; changing the individual activities of the personnel into a group activity; and encouraging anticipation in the personnel and managers.

\section{Concluding Remarks}

The purpose of this study was to discuss different aspects of strategic management and to shed more lights on this issue. In addition, this paper tried to consider the importance of implementing strategic management in modern organizations to achieve future objectives.

To achieve the purpose of this study, the five Ps of strategy, namely strategy as plan, ploy, pattern, position, and strategy as perspective were introduced and the cycle of strategic management which was composed of planning, execution, and monitoring developments and progress was presented. Finally, it was found that through collecting and evaluating data about the internal and external factors, strategic management can help the organizations get information about their own present status, so that their strengths and weaknesses are 
specified and the opportunities, the probable threats, and the rivals of the organization are recognized. Then, having enough information, the objectives are determined and realistic strategic plans are developed and implemented.

In conclusion, it should be mentioned that this study was a descriptive research which dealt with different theoretical issues related to strategic management. Therefore, the experimental study of the issue in different kind of organizations and companies can be addressed in future studies to make more contribution toward the field.

\section{References}

Al Hijji, K. Z. (2014). Strategic management model for academic libraries. Procedia - Social \& Behavioral Sciences 147, 915.

Ali-Ahmadi, A., Taj al-Din, I., \& Fethullah, M. (2012). Comprehensive approach to strategic management. Tehran, Iran: Knowledge Production.

Andrews, K. R. (1971). The concept of corporate strategy. Homewood, IL: Irwin.

Ansoff. H. I. (1965). Corporate strategy. New York, NY: McGraw-Hill.

Barrett, R. (2003). Vocational business: Training, developing and motivating People. Cheltenham, United Kingdom: Nelson Thornes.

Chandler, A. D. Jr. (1962). Strategy and structure: Chapters in the history of the American industrial enterprise. Cambridge, MA: MIT Press.

Daft, R. L. (2010). Organization theory and design. Boston, MA: Cengage Learning.

Davari, D. (2001). Strategic management: From theory to practice. Tehran, Iran: Athena.

David, F. R. (2006). Strategic management: Concepts and cases (11 ${ }^{\text {th }}$ ed.). London, United Kingdom: Prentice-Hall.

Drucker, P. F. (1974). Management: Tasks, responsibilities, practices. New York, NY: Harper \& Row.

Galloway, I. D. (1990). Strategic management in public sector research organizations: A critical review. International Journal of Public Sector Management, 3(1), 5-24.

Gannon, J. M., Roper, A., \& Doherty, L. (2015). Strategic human resource management: Insights from the international hotel industry. International Journal of Hospitality Management, 47, 65-75.

Glueck, W. F. (1976). Business policy, strategy formation and management action (2 ${ }^{\text {nd }}$ ed.). New York, NY: McGraw Hill.

Guerras-Martin, L. A., Madhok, A., \& Montoro-Sanchez, A. (2014). The evaluation of strategic management research: Recent trends and current directions. BRQ Business Research Quarterly, 17(2), 69-76.

Lengnick-Hall, M. L., Lengnick-Hall, C. A., \& Rigsbee, C. M. (2013). Strategic human resource management and supply chain orientation. Human Resource Management Review, 23(4), 366-377.

Najaf-Beigi, R. (2011). Organization and management ( $7^{\text {th }}$ ed.). Tehran, Iran: Termeh.

Mintzberg, H. (1987). The strategy concept I: Five Ps for strategy. California Management Review, 30(1), 11-24.

Safi, A. (1995). Management and planning in education ( $3^{\text {rd }}$ ed.). Tehran, Iran: In-Service Education Office.

Yorio, P. L., Willmer, D. R., \& Moore, S. M. (2015). Health and safety management systems through a multilevel and strategic management perspective: Theoretical and empirical considerations. Safety Science, 72, 221-228. 